\title{
PROGRAM PENGAJARAN DAN PELATIHAN BAHASA INGGRIS DAN MATEMATIKA DASAR DI YAYASAN AL KAMILAH KELURAHAN SERUA KECAMATAN BOJONGSARI KOTA DEPOK
}

\author{
Eko Sasongko Priyadi ${ }^{\text {a,1 }}$, Fitriyah ${ }^{\text {b,2 }}$, Eny Suryani ${ }^{\text {c,3 }}$, Juitania ${ }^{\text {d,4 }}$, \\ S1 Akuntansi, Fakultas Ekonomi, UniversitasPamulang \\ *korespondensi penulis : eny.suryani.hadi@gmail.com
}

\begin{abstract}
Abstrak
Salah satu permasalahan yang dihadapi oleh masyarakat marginal di pinggiran kota, baik marginal secara ekonomi maupun marginal akses sumber daya adalah terbatasnya akses pada dunia pendidikan. Ketidakmampuan ekonomi dan jauhnya sekolah umum sebagai sarana formal pendidikan menyebabkan mereka memiliki keterbatasan untuk mendapatkan salah satu haknya. Dalam jangka panjang, kondisi ini dapat berakibat pada rendahnya tingkat mobilitas vertikal untuk mendapatkan kehidupan yang lebih baik di masa datang. Sebagai salah satu metode untuk ikut mengatasi permasalahan ini, beberapa staf pengajar pada Prodi Akuntansi Universitas Pamulang melaksanakan program pengajaran dan pelatihan Bahasa Inggris dan Matematika Dasar di Yayasan Al Kamilah, Bojongsari Kota Depok. Program ini dikeman menjadi salah satu wujud dari pelaksanan tri darma perguruan tinggi yakni Pengabdian Kepada Masyarakat.
\end{abstract}

Kata-kata kunci: Pengajaran, Pelatihan, Bahasa Inggris, Matematika Dasar

\begin{abstract}
One of the problems faced by marginal communities in the suburbs, both economically marginal and marginal access to resources is limited access to education. The economic inability and distance of public schools as a formal means of education cause them to have limitations in getting one of their rights. In the long run, this condition can result in a low level of vertical mobility to get a better life in the future. As one method to help overcome this problem, several teaching staff at the University of Pamulang Accounting Study Program conduct teaching and training programs in English and Basic Mathematics at the Al Kamilah Foundation, Bojongsari, Depok City. This program is believed to be one form of the tri darma implementation of higher education namely Community Service.
\end{abstract}

Keywords: Teaching, Training, English Language, Basic Mathematic

\section{PENDAHULUAN}

Negara Indonesia yang memanjang dari Sabang hingga Merauke memiliki berbagai permasalahan sosial yang hingga kini masih belum dapat diatasi. Berbagai permasalahan sosial tersebut adalah ketimpangan ekonomi, kemiskinan, tingginya angka pengangguran, pertumbuhan penduduk yang tidak 
terkendali, naiknya angka kejahatan dan semakin tergerusnya pedesaan oleh pembangunan. Salah satu permasalah sosial yang kasat mata dan telah menjadi isu nasional sejak lama adalah ketimpangan antara Pulau Jawa dengan pulau di luar Jawa, Wilayah Indonesia Bagian Barat dengan Indonesia Bagian Timur serta ketimpangan antara daerah perkotaan dengan pedesaan. Dampaknya, sebagian masyarakat sulit mendapatkan akses terhadap kebutuhan dasar yang menjadi haknya seperti memperoleh pendidikan. Kondisi ini terjadi karena sebagian masyarakat memiliki keterbatasan finansial untuk memperoleh pendidikan.

Fakta ini dapat terlihat di daerahdaerah pedesaan atau daerah sub-urban, suatu daerah yang terletak antara daerah perkotaan dan pedesaan. Daerah sub-urban ini menjadi penyangga bagi kota-kota besar dalam penyedia tenaga kerja dan sumber daya lainnya. Karakteristik fisik daerah ini adalah kondisi infrastruktur yang sudah lebih baik dibandingkan wilayah pedesaan akibat pembangunan fisik yang terus berlangsung. Pembangunan ini terjadi karena pertumbuhan secara masif komplekkomplek perumahan penduduk akibat derasnya arus migrasi dari desa dan orang yang bekerja di kota namun memilih tempat tinggal di pinggiran kota.
Di sisi lain, daerah sub-urban merupakan daerah yang memiliki karakteristik belum menjadi kota karena lokasinya yang berdekatan dengan daerah pedesaan dan masih banyaknya pemukimanpemukiman bercorak perkampungan padat. Berbeda dengan kota yang dikelilingi gedung-gedung bertingkat, perkantoran dan area bisnis, berbagai fasilitas pasar dan mall modern, sarana olah raga yang eksklusif, sarana transportasi yang handal, maka pada wilayah sub-urban ini lebih didominasi oleh permukiman penduduk dan lokasi yang tidak dikelilingi oleh gedung-gedung perkantoran dan bisnis. Sub-urban ini menjadi penyangga bagi kota metropolitan seperti Jakarta karena menjadi penyedia tenaga kerja bagi kota tersebut.

Salah satu kota penyangga Jakarta adalah Depok. Terletak di sebelah selatan Jakarta, Depok berkembang sangat pesat, khususnya setelah masuknya Universitas Indonesia dan Universitas Gunadarma. Pemekaranpun terus terjadi. Beberapa desa dan kecamatan yang awalnya berada di bawah administrasi Kota Bogor dan Tangerang, kini telah menjadi bagian dari Kota Depok. Salah satunya adalah Kelurahan Serua yang akan menjadi lokasi PKM, di mana berdiri Yayasan Al Kamilah sebagai pusat lokasi kegiatannya. 
Gambaran Umum Lokasi

Kelurahan Serua terletak di Kecamatan Bojongsari, Kota Depok. Kelurahan ini berbatasan dengan Kecamatan Pamulang, Kabupaten Tangerang Selatan. Dilalui jalan Ciputat - Parung - Bogor yang merupakan jalan nasional. Akses menuju lokasi Yayasan Al Kamilah relatif mudah. Dari pusat Kota Depok dapat dijangkau melalui Jalan Raya Sawangan dan menuju utara melalui Jalan Raya Ciputat-Bogor ke arah Jakarta. Sedangkan dari arah Ciputat dan Pamulang, lokasi ini dapat dicapai melalui jalan yang sama menuju Bogor.

Perkembangan Kelurahan Serua saat ini sangat pesat. Dengan kasat mata dapat terlihat pembangunan komplek-komplek perumahan baru di lahan-lahan yang masih kosong. Lokasinya yang berdekatan dengan jalan nasional yang merupakan akses utama menuju Jakarta menjadikan lokasi ini sangat strategis untuk tempat tinggal karena akan memudahkan orang untuk mencapai tempat kerja baik di Jakarta maupun Bogor. Namun, di sisi lain berkembang pula pemukimanpemukiman padat karena banyaknya rumahrumah kontrakan. Lokasinya yang jauh dari pusat kota, namun dekat dengan jalan raya, menjadi faktor utama orang memilih lokasi ini karena ongkos kontrakan yang terjangkau.
Akibat dari masifnya pembangunan perumahan baru dan munculnya pemukiman padat, menjadikan daerah ini juga rawan angka kejahatan. Sekalipun belum ada angka konflik sosisal antara penduduk lama dengan penduduk baru, namun wilayah di sekitar Kelurahan Serua sangat rawan dengan pencurian dan pembegalan motor. Beberapa kasus pembegalan motor yang menimbulkan korban pernah terjadi di sekitar wilayah ini, khususnya di Kecamatan Cinangka yang berbatasan langsung dengan Kecamatan Bojongsari.

Beberapa faktor penyebabnya di antaranya Penerangan di lokasi kejahatan tersebut masih kurang, sehingga masih banyak tempat-tempat yang gelap, Kurangnya lapangan pekerjaan yang menyebabkan orang tidak memiliki penghasilan untuk mencukupi kebutuhan hidupnya sehari-hari, Faktor pendidikan yang rendah yang menyebabkan orang di sekitar lokasi kejadian tidak dapat masuk dunia kerja,

Tingkat ekonomi yang rendah karena sebagian penduduk menggantungkan sumber pendapatannya pada dagang kecilkecilan, masifnya pendatang dari luar daerah tanpa keahlian dan sumber pendapatan yang cukup sehingga orang dapat berbuat jahat untuk memenuhi kebutuhan hidupnya. Pendidikan juga menjadi masalah bagi 
masyarakat di sekitar Keluarahan Serua. Hampir tidak ada sarana sekolah menengah atas negeri yang dekat dengan masyarakat. Mayoritas SMA negeri berada di pusat kota, yakni di sekitaran Depok 1, Depok 2, Depok Timur dan Cimanggis. Kondisi ini menyebabkan anak usia sekolah sulit memperoleh akses pendidikan murah dan berkualitas akibat tidak adanya sekolah negeri pada jenjang sekolah menengah atas.

Untuk turut menangani berbagai permasalahan di atas, Yayasan Al Kamilah yang terletak di Kelurahan Serua, Kecamatan Bojongsari berkiprah dalam membantu persoalan masyarakat, khususnya pada masyarakat tidak mampu. Yayasan ini menampung anak-anak yang memiliki keterbatasan ekonomi karena tidak memiliki orang tua atau orang tua yang menitipkan anaknya di yayasan ini untuk mendapatkan hak dasarnya, yakni hak hidup, hak pemenuhan kebutuhan jasmani, hak pemenuhan kebutuhan rohani, kesehatan dan pendidikan.

Namun, bidang pendidikan yang dilaksanakan oleh yayasan ini hanya berfokus pada bidang pendidikan agama saja. Ada beberapa analisa mengapa pendidikan agama menjadi fokus pengajaran pada yayasan ini:
1. Ilmu agama merupakan ilmu yang menjadi dasar sebelum mendapatkan ilmu pengetahuan lainnya,

2. Kondisi masyarakat sub-urban di sekitar lokasi pelaksanaan PKM ini merupakan masyarakat yang religius sehingga pendalaman ilmu agama menjadi pedidikan yang penting untuk diberikan kepada anak-anak usia sekolah agar mereka menjadi anak yang baik, tidak akan menimbulkan masalah di masa depan dan ilmu agama ini dapat menjadi pegangan hidup saat menghadapi kehidupan nyata di luar yayasan.

3. Sebagian yayasan di Indonesia yang memiliki perhatian kepada masyarakat tidak mampu, anak yatim dan lainnya memang lebih berfokus pada pendidikan agama,

4. Pendidikan agama di pandang pendidikan murah karena bersandarkan pada keikhlasan staf pengajarnya

5. Tidak banyak pengajar mata pelajaran umum yang memiliki perhatian pada masyarakat tidak mampu dan anak yatim, serta mau terlibat mendedikasikan ilmunya bagi mereka.

Oleh karena itu, untuk mengisi kekosongan mata pelajaran umum yang tidak diberikan oleh yayasan dan untuk memenuhi kebutuhan dasar pendidikan bagi anak-anak usia sekolah yang di bina di 
yayasan ini, khususnya Bahasa Inggris dan Matematika, kami staf pengajar di Universitas Pamulang mengajukan usulan pelaksanaan PKM di yayasan ini.

\section{Metode Pelaksanaan}

Pelaksanaan program pengajaran dan pelatihan Matematika Dasar dan Bahasa Inggris Pada Anak Usia Sekolah di Yayasan Al Kamilah Kelurahan Serua, Kecamatan Bojongsari, Kota Depok ini dilaksanakan setiap pekan. Dimulai tanggal 13 November 2019 dan berakhir tanggal 4 Desember 2019. Program Pengabdian Kepada Masyarakat ini bekerjasama pula dengan Program Pengabdian kepada Masyarakat dua kelompok lainnya yang melaksanakan kegiatan sejak awal September hingga pertengahan November.

Tujuan berkolaborasi dengan kelompok PKM lain adalah agar peserta, memperoleh materi pelajaran yang lebih terstruktur, terencana dan berkelanjutan sehingga Program Pengabdian Kepada Masyarakat ini bukan merupakan kegiatan yang bersifat insidental atau satu hari selesai. Namun pula, terdapat hubungan yang intens sehingga tim-PKM pun mendapat gambaran yang utuh tentang permasalahan umum dan kebutuhan dasar yang diperlukan oleh anak-anak usia sekolah di yayasan tersebut.

\section{PELAKSANAAN KEGIATAN}

Kegiatan program pengajaran dan pelatihan Bahasa Inggris dan Matematika Dasar ini di setiap pekan sebagai berikut. Pemberi materi merupakan staf pengajar pada Fakultas Ekonomi Universitas Pamulang. Pelaksanaan kegiatannya adalah sebagai berikut:

1. Tanggal 13 November 2019. Pemberi materi: Fitriyah, S.Pd., M.Pd. Materi: Bahasa Inggris. Memberikan materi tentang daily activities. Fitriyah, S.Pd., M.Pd, menamatkan jenjang pendidikan S-1 pada Fakultas Pendidikan Bahasa Inggris Sekolah Tinggi Keguruan dan Ilmu Pendidikan PGRI Bandar Lampung. Dilanjutkan dengan jenjang pendidikan S-2 yang berhasil ditamatkannya di Program Pasca Sarjana Bahasa Inggris Universitas Negeri Semarang.

2. Tanggal 20 November 2019. Pemberi materi: Eko Sasongko Priyadi, S.Sos, M.A. Materi: Bahasa Inggris. Menamatkan Program S1pada Jurusan Antropologi Fakultas Ilmu Sosial dan Ilmu Politik Universitas Indonesia dan dilanjutkan dengan menamatkan Program Master pada Departemen Area Studies Sophia University, 
Tokyo, Jepang. Sempat pula melenjutkan Program Doktoral pada Departemen Global Studies di Sophia University, Tokyo, Jepang yang belum diselesaikan.

3. Tanggal 27 November 2019. Pemberi materi: Dra. Enny Suryani, M.Pd. Materi: Matematika Dasar. Dra Enny Suryani, M.Pd menyampaikan materi tentang "Pembahasan soal-soal UNBK".

4. Tanggal 4 Desember 2019. Pemberi materi: Juitania, S.Pd., M.Pd. Materi: Bahasa Inggris. Juitania S.Pd., M.Pd menamatkan pendidikan S-1 pada Fakultas Ilmu Pendidikan dan Keguruan Universitas Pakuan. Dilanjutkan dengan menamatkan jenjang S-2 pada Program Pasca Sarjana Universitas PGRI Indraprasta dengan kekhususan Program Studi Pendidikan Bahasa Inggris. Juitania, S.Pd., M.pd memberikan materi tentang "Dominos Game and Regular Activities".

Pengajaran dan Pelatihan dilaksanakan di Yayasan Al Kamilah yang berlokasi di Jalan Serua Raya, Kecamatan Bojongsari, Kota Depok, Jawa Barat. Kegiatan dilaksanakan seusai jadual di atas. Namun, bila terdapat kendala atau hambatan yang menyebabkan pelaksanaan kegiatan sulit direalisasi pada jadual di atas, maka pelaksanaannya akan diganti pada hari lain dengan tidak mengurangi bahan materi yang dijadualkan.

Peran serta partisipasi peserta adalah dengan menghadiri dan mengikuti program pengajaran dan pelatihan secara aktif. Pemberi materi akan menyampaikan bahan pembelajaran secara interaktif dan menyenangkan. Pemberian materi ini akan menyesuaikan dengan usia dan kemampuan peserta yang berdasarkan data itu sangat beragam.

Selain anak usia sekolah di Yayasan Al Kamilah, peran serta aktif pengelola yayasan juga menjadi dukungan yang sangat baik untukkeberhasilan program ini. Tanpa dukungan pengelola yayasan, tidak mungkin kemampuan dan wawasan anak usia sekolah di tempat tersebut dapat ditingkatkan.

\section{HASIL DAN PEMBAHASAN}

Berdasarkan uraian di atas, maka salah satu cara untuk dapat meningkatkan pendidikan dan kemampuan di Yayasan Amaliah yang menampung dan membina anak-anak tidak mampu adalah dengan memberikan pengajaran dan pelatihan pada mata pelajaran yang tidak diberikan. Idealnya, pengajaran dan pelatihan ini diberikan pada seluruh mata pelajaran agar 
mereka dapat mengikuti perkembangan zaman dan menjadi sumber daya manusia yang berkualitas. Bila komponen ini dapat dicapai maka mereka dapat bersaing di dunia kerja dan melakukan mobilitas sosial yang akan meningkatkan taraf hidup dan status sosial ekonominya di masa yang akan datang

Namun, pada tahap awal ini tidak seluruh mata pelajaran diberikan. Keterbatasan dana dan sumber daya pengajar masih menjadi kendala utama. Selain itu, karena pelaksanaan program pengajaran dan pelatihan ini masih merupakan tahap awal yang dipadukan dalam Program Pengabdian Kepada Masyarakat, maka belum apa saja yang menjadi kebutuhan ideal anak-anak tersebut. Oleh karena itu, pada tahap awal ini hanya akan diberikan pada dua mata pelajaran, yakni Matematika dan Bahasa Inggris.

Beberapa faktor yang melatarbelakangi mengapa hannya dua mata pelajaran ini yang difokuskan pada program pengajaran dan pelatihan PKM saat ini yakni:

Seluruh staf pengajar yang terlibat dalam Program Pengabdian Kepada Masyarakat ini adalah staf pengajar memiliki latar belakang Matematika dan Bahasa Inggris. Dalam tugas keseharian mengajar di Universitas Pamulang, seluruh staf pengajar ini mengampu atau memberikan kuliah pada mahasiswa pada mata kuliah Matematika dan Bahasa Inggris, Seluruh pengajar ini telah mengampu mata kuliah Bahasa Inggris dan Matematika di Universitas Pamulang selama beberapa tahun,

Berdasarkan informasi yang diberikan oleh pembina yayasan, bahwa kebutuhan mata pelajaran yang diberikan adalah mata pelajaran umum yang hingga saat ini belum dapat diberikan oleh pihak yayasan. Sehingga pengajaran dan pelatihan Matematika dan Bahasa Inggris menjadi kebutuhan bagi anak-anak di yayasan,

Matematika dan Bahasa Inggris adalah mata pelajaran yang sangat dibutuhkan dalam kehidupan sehari-hari, khususnya di dunia kerja. Di era globalisasi saat ini, di mana masyarakat suatu bangsa sangat membutuhkan bangsa lain maka komunikasi dengan Bahasa Inggris merupakan suatu kebutuhan yang tidak terelakkan. Hubungan antar bangsa dapat terjalin jika terjadi komunikasi yang dapat di mengerti oleh seluruh pihak. Suatu bangsa dapat menyampaikan ide dan gagasan kepada bangsa lain untuk saling bekerja sama dalam berbagai bidang. Tentunya, agar ide dan gagasan itu dapat di mengerti dan dipahami oleh bangsa sehingga ide dan gagasan tersebut dapat diterima, maka 
kemampuan dalam berkomunikasi Bahasa Inggris menjadi keniscayaan, Bahasa Inggris telah ditetapkan menjadi bahasa internasional yang digunakan dalam berbagai forum-forum resmi, baik di tingkat regional seperti ASEAN, Asia-Pasific maupun tingkat internasional seperti forum di tingkat ASIA maupun PBB.

Globalisasi telah membuat dunia menjadi kecil dan tanpa batas antar negara. Batas-batas antar negara menjadi hilang. Apalagi, di berbagai kawasan, baik regional maupun internasional telah menetapkan kesepakatan perdagangan bebas yang membuat masyarakat suatu bangsa bebas masuk ke negara lain. Bila tidak memiliki kemampuan berkomunikasi dalam Bahasa Inggris maka masyarakat Indonesia tidak dapat berkompetisi untuk masuk ke dunia kerja di tingkat internasional.

Matematika juga menjadi pelajaran dasar yang prakteknya sangat mudah ditemukan dalam kehidupan manusia seharihari. Proses jual-beli, untung-rugi, perdagangan, perhitungan jarak dengan harga dan proses lainnya adalah contohcontoh penerapan ilmu matematika dalam kehidupan sehari-hari. Oleh karena itu, pemahaman dasar tentang matematika juga menjadi kebutuhan yang tidak dapat dihindari
Namun, agar seseorang dapat berkompetisi dan menjadi sumber daya manusia yang unggul, tentu tidak cukup hanya mengandalkan pada dua mata pelajaran ini saja. Perlu ditambah dengan bidang-bidang yang lain. Harapannya, pada masa-masa berikutnya, mata pelajaran yang lain juga dapat diajarkan mereka memiliki wawasan yang luas

Selain metode pengajaran dan pelatihan, solusi yang diitawarkan kepada yayasan adalah kebutuhan finansial. Pengertiannya, seluruh kegiatan dalam program PKM ini dibebankan kepada penyelenggara, dalam hal ini adalah tim PKM dari Universitas Pamulang. Dengan model pembiayan yang dibebankan kepada tim pelaksana PKM diharapkan permasalahan finansial yang mungkin dihadapi oleh pengelola yayasan dapat di atasi.

\section{KESIMPULAN}

Pelaksanaan Program Pengajaran dan Pelatihan Bahasa Inggris dan Matematikan Dasar di Yayasan Al Kamilah memberikan satu alternatif metode pelaksanaan Pengabdian Kepada Masyarakat. Pemberian materi secara intens dan berkelanjutan memberikan manfaat dan dampak positif yang besar kepada masyarakat yang memiliki akses minimum 
pada beberapa bidang kehidupan mereka. Penerapan metode dengan berkolaborasi dengan beberapa kelompok PKM lainnya akan memberikan hasil yang optimal bagi penerima program PKM ini. Sekalipun materi yang diberikan oleh nara sumber merupakan materi-materi dasar, namun bagi penerima program sangat dirasakan manfaatnya. Program-program dengan metode di atas dapat dilanjutkan pada mata pelajaran - mata pelajaran lain sehingga wawasan masyarakat, terutama masyarakat yang memiliki akses minimum pada beberapa bidang kehidupan menjadi terbuka dan memberi peluang untuk berkompetisi dengan masyarakat yang memiliki akses besar pada banyak bidang kehidupan.

\section{REFERENSI}

Aini, Y. (2015). Pengaruh Pembelajaran Kewirausahaan terhadap Minat Mahasisw UPP Berwirausaha. Jurnal Ilmiah Cano Ekonomos, 3(1), 69-78. https://doi.org/https://doi.org/10.5281/z enodo.571256

Christianingrum, \& Rosalina, E. (2017). Pengaruh Pembelajaran Kewirausahaan terhadap Motivasi Berwirausaha. Integrated Journal of Business and
Economics (IJBE), 1(1), 45-55. https://doi.org/10.17509/strategic.v18i1 .17583

Jailani, H., Fahrurrozi, M., \& Rizqi, Y. A. (2017). Pengaruh Pembelajaran Kewirausahaan terhadap Minat dan Motivasi Berwirausaha Siswa di SMK Negeri 1 Selong Tahun Pelajaran 2016. JPEK, 1(1), 49-56.

Mahanani, E., \& Sari, B. (2018). FaktorFaktor yang Mempengaruhi Minat Berwirausaha Mahasiswa Fakultas Ekonomi Universitas Persada Indonesia Y.A.I. Ikraith-Humaniora, 2(2), 31-40. Mardetini, E., Jaenudin, R., Fatimah, S., Firmansyah, \& Amrina, D. E. (2017). Peningkatan Pengetahuan dan Minat Berwirausaha pada Industri Kreatif di Kecamatan Pemulutan Ogan Ilir. Jurnal Pemberdayaan Masyarakat Madani (JPMM), 1(2), 207-229. https://doi.org/10.21009/jpmm.001.2.0 5

Ozaralli, N., \& Rivenburgh, N. K. (2016). Entrepreneurial intention: antecedents to entrepreneurial behavior in the U.S.A. and Turkey. Journal of Global Entrepreneurship Research, 6(3), 1-32. https://doi.org/10.1186/s40497-0160047-x

Primandaru, N. (2017). Analisis FaktorFaktor yang Berpengaruh pada Minat 
Berwirausaha Mahasiswa. Jurnal

Economia, $\quad$ 13(1), 68-78.

https://doi.org/10.21831/economia.v13i

1.13276

Royyan, M. I. (2017). Pengaruh

Keterampilan Mengadakan Variasi

Mengajar terhadap Motivasi Belajar

Siswa pada Mata Pelajaran Sejarah

Kebudayaan Islam Kelas VII MTs

Ma'arif NU 1 Karanglewas Kabupaten

Banyumas ([Skripsi]). Purwokerto:

IAIN Purwokerto.
Setyowati, E. (2012). Faktor-faktor yang Berpengaruh terhadap Hasil Belajar Bahasa Inggris Siswa SMP di Yogyakarta ([Tesis]). Yogyakarta: Program Pascasarjana Universitas Negeri Yogyakarta.

Wijayangka, C., Kartawinata, B. R., \& Novrianto, B. (2018). Pengaruh Motivasi terhadap Minat Berwirausaha Mahasiswa Program Studi Administrasi Bisnis Universitas Telkom. ECo-Buss, 1(2), 73-79. 